\title{
IMPACT OF INFORMATION LITERACY SKILLS ON THE USE OF E-LIBRARY RESOURCES AMONG TERTIARY INSTITUTION STUDENTS IN AKWA IBOM STATE
}

\author{
U. O. Ekong ${ }^{1}$ and V. E. Ekong ${ }^{2, *}$ \\ 1, 2 DePartment of Computer SCIEnCe, FACUlty of SCIENCE, University of Uyo, AKWA IBOM STATE, NiGERIA \\ E-mail addresses: ${ }^{1}$ uyinomenekong@uniuyo.edu.ng, ${ }^{2}$ victoreekong@uniuyo.edu.ng
}

\begin{abstract}
The study investigated the influence of information literacy skills on the use of e-library resources in tertiary institutions in Akwa Ibom State. Students need information for a variety of activities and the e-library is a resource center for providing a wide range of electronic resources that can meet any academic purpose. However, the use of electronic resources is largely dependent on the skills and information literacy of the students. An empirical survey was carried out to examine the impact of computer literacy skills among undergraduate students in tertiary institutions in Akwa Ibom state on the use of e-library resources. A total of 500 questionnaires were administered and analyzed using ANOVA. The study reveal that the quality and volume of academic work is largely influenced by the knowledge and skills possessed in the use of e-library resources. It therefore concluded that students in tertiary institutions need to update their information literacy skills.
\end{abstract}

Keywords: Information, Literacy Skills, Institution, e-Library, e-resources

\section{INTRODUCTION}

Information literacy is the capability of individuals to locate and critically evaluate information. It is also the ability to make effective use of information in decision making and knowledge creation [1]. The library is the heart of any academic institution as it helps to provide, inform and educate the students through books, journals, audio visual materials and services. Higher institutions all over the world place high emphasis on qualitative and quantitative research products to fulfill their mission of teaching, learning, research and cultural development. The measure of value placed on any institution is determined by the access to right information and level of information literacy of the students and faculties which automatically affect the research output of that institution. In [2], researches do not only help to solve practical problems and bring about material improvements, it also provides insights into new ideas that improve human understanding of various social, economic and cultural phenomena. Research has always been the main approach to solving problems by all categories of professional [3].

With the rapid advancement of Information Technology (IT) the library system has also revolutionized. Institutional libraries are now categorized with dynamic electronic resources as against the traditional printed paper material. Academics and students now have unrestricted accesses to global digital information resources, particularly through the internet for scholarly communication and publications $[4,5]$. These have also resulted into diverse challenges, competitions, demands, expectations and provision of quality and correct information as at when needed. On the other hand, the ability to access, retrieve and evaluate information is not enough. Users of information resources must possess information literacy skills in other to harness information resources at their disposal adequately. Knowledge and techniques for exploring information for problem solving and decision making in the ever changing IT world has birthed the information literacy skills which enables information users in the acquisition of necessary information. Information users are faces with countless information choices and must decide which resource(s) to use in the acquisition of information. They also determine the authenticity, validity, and usability of the information they discover [6]. 
United Nations Educational Scientific and Cultural Organization (UNESCO) Information For All Programme (IFAP) defines information literacy as the capacity of people to recognize their information needs; locate and evaluate the quality of information; store and retrieve information; make effective and ethical use of information and simultaneously apply information to create an communicate knowledge [7]. Information literacy is a lifelong learning process $[8,9]$. Information literacy skills is a fusion of library literacy, computer literacy, media literacy, technological literacy, critical thinking, ethics and communication, which when acquired would enable users of information to become independent[8].

This paper focuses on the impact of information literacy skills required for effective use of information resources for research productivity by students in tertiary institutions in Akwalbom State. An empirical survey is carried out and analyzed to determine the level of information literacy and skills possessed by students for the use e-library e-resources.

\section{RELATED WORKS}

University library is the hub of any university world over, with the mission of supporting educational objectives which include teaching, learning, research, and community development through provision of adequate information and through books, journal, encyclopedias, audio-visual collections, magazines, and so on [10]. Over the years there has been some level of transformation in the use of library resources for information provision and dissemination. The traditional method of arranging resources material on shelves which is very difficult to maintain is gradually giving way to the use of modern information system through the use of computers and other communication channels such as the internet in providing adequate and timely information as at when needed [11, 12]. Electronic resources (e-resources) are those information resources that can only be accessed by the use of computers and other ICT devices. Eresources are potentially powerful tools for extending educational opportunities which are popularly used by students for timely information retrieval, ability to search multiple files at the same time and convenience in remote accesses. The use of e-resources has given rise to new modes of organizing the educational environment in tertiary institutions and introduced new concept in the teaching and learning process. However, [13] reports a positive correlation in students with high self-efficacy regarding computers would be more likely to explore new techniques, software or database to attain certain level of performance. Table 1 further reports some related work.

Table 1: Some Related Work

\begin{tabular}{|c|c|c|c|c|}
\hline $\mathrm{S} / \mathrm{N}$ & Paper Title & Author(s) & $\begin{array}{l}\text { Instrument of Data } \\
\text { Collection/Population size }\end{array}$ & Findings \\
\hline \multirow[b]{3}{*}{1.} & \multirow{3}{*}{$\begin{array}{l}\text { Factors that influence } \\
\text { the use of library } \\
\text { resources by students } \\
\text { in TEI, Greece. }\end{array}$} & \multirow[b]{3}{*}[14]{} & \multirow[b]{3}{*}{ Questionnaire } & $\begin{array}{l}\text { 1. Majority of the students used } \\
\text { printed sources more than e- } \\
\text { resources }\end{array}$ \\
\hline & & & & $\begin{array}{l}\text { 2. e-resources mostly used was } \\
\text { website }\end{array}$ \\
\hline & & & & $\begin{array}{l}\text { 3. inability to locate most of the e- } \\
\text { resources due to low/no } \\
\text { accessibility to internet, low } \\
\text { speed, low capacity of computers } \\
\text { retrieval problems as well as } \\
\text { poor internet search technique. }\end{array}$ \\
\hline
\end{tabular}

Effects of availability and accessibility on the utilization of

2. library Resources at MichealOkpara University, Umudike, Nigeria.
Questionnaire using simple percentage and frequency tables with 168 respondents
That the use of library resources depends greatly on accessibility of information. however the study suffers from narrow scope and emphasis on the university sector. 


\begin{tabular}{|c|c|c|c|c|}
\hline $\mathrm{S} / \mathrm{N}$ & Paper Title & Author(s) & $\begin{array}{l}\text { Instrument of Data } \\
\text { Collection/Population size }\end{array}$ & Findings \\
\hline 3. & $\begin{array}{l}\text { Utilization of } \\
\text { university facilities: a } \\
\text { case study of cross } \\
\text { River State University } \\
\text { of Technology Calabar. }\end{array}$ & [16] & $\begin{array}{l}\text { Questionnaire using simple } \\
\text { descriptive statistics of } \\
\text { mean and standard } \\
\text { deviation with } 434 \\
\text { respondents }\end{array}$ & $\begin{array}{l}\text { Low rate of students' usage of } \\
\text { library resources. Library } \\
\text { resources only used for term } \\
\text { paper preparation and research. }\end{array}$ \\
\hline 4. & $\begin{array}{l}\text { Accessibility and use } \\
\text { of library resources by } \\
\text { undergraduates in } \\
\text { LadokeAkintola } \\
\text { University of Science } \\
\text { and Technology, } \\
\text { Ogbomoso, Nigeria. }\end{array}$ & [17] & $\begin{array}{l}\text { Questionnaire using simple } \\
\text { descriptive statistics and } \\
\text { SPSS with } 600 \text { respondents }\end{array}$ & $\begin{array}{l}\text { Majority of the student do not use } \\
\text { e-resources. }\end{array}$ \\
\hline 5. & $\begin{array}{l}\text { Students perceived } \\
\text { effectiveness in the } \\
\text { use of library } \\
\text { resources in some } \\
\text { selected Nigerian } \\
\text { universities. }\end{array}$ & {$[18]$} & $\begin{array}{l}\text { Questionnaire using simple } \\
\text { descriptive statistics and } \\
\text { percentage tabulation with } \\
530 \text { respondents }\end{array}$ & $\begin{array}{l}\text { There is effective user education } \\
\text { in the University of Calabar for } \\
\text { the library users than that } \\
\text { obtained in University of Uyo. }\end{array}$ \\
\hline 6. & $\begin{array}{l}\text { Assessment of the } \\
\text { utilization of Makerere } \\
\text { university electronic } \\
\text { information resources } \\
\text { by academic staff: } \\
\text { challenges and } \\
\text { prospects. }\end{array}$ & [19] & $\begin{array}{l}\text { Questionnaire, interview } \\
\text { and document analysis tools } \\
\text { using Statistical Package for } \\
\text { Social Sciences (SPSS) with } \\
300 \text { respondents. }\end{array}$ & $\begin{array}{l}\text { Majority of the respondents were } \\
\text { aware of the e-resources } \\
\text { available in the library. E- } \\
\text { resources are used mainly for } \\
\text { publication purposes, } \\
\text { preparation for conferences and } \\
\text { teaching. } \\
\text { Slow speed, lack of publicity, } \\
\text { limited subscription to databases, } \\
\text { and poor user skill were } \\
\text { identified as inhibiting factors }\end{array}$ \\
\hline 7. & $\begin{array}{l}\text { Information literacy } \\
\text { skills and information } \\
\text { use by students in } \\
\text { university of Uyo and } \\
\text { Port Harcourt } \\
\text { Libraries }\end{array}$ & {$[20]$} & $\begin{array}{l}\text { Questionnaire using mean } \\
\text { score and person product } \\
\text { moment correlation } \\
\text { coefficient (PPMC) to collect } \\
\text { and analyze the hypothesis } \\
\text { respectively with 2,758 } \\
\text { respondents }\end{array}$ & $\begin{array}{l}\text { There is a significant relationship } \\
\text { between literacy skills and } \\
\text { information use by students }\end{array}$ \\
\hline 8. & $\begin{array}{l}\text { Effects of Information } \\
\text { Literacy on the Use of } \\
\text { E-Library Resources } \\
\text { among students of the } \\
\text { University of Ilorin, } \\
\text { Kwara State. }\end{array}$ & [21] & $\begin{array}{l}\text { Questionnaire and interview } \\
\text { using simple percentage and } \\
\text { frequency tabulation with } \\
415 \text { respondents }\end{array}$ & $\begin{array}{l}\text { Information literacy skills are yet } \\
\text { to be fully harnessed among } \\
\text { students of the institution as a } \\
\text { result of inadequate teaching aids } \\
\text { for acquisition of the skills. }\end{array}$ \\
\hline 9. & $\begin{array}{l}\text { Undergraduates' } \\
\text { Information Literacy } \\
\text { Skills and the use of } \\
\text { Electronic Resources } \\
\text { in Delta State } \\
\text { University, Abraka }\end{array}$ & {$[22]$} & $\begin{array}{l}\text { Questionnaire using simple } \\
\text { percentage and frequency } \\
\text { tabulations with } 610 \\
\text { respondents }\end{array}$ & $\begin{array}{l}\text { Majority of the student are well } \\
\text { versed with information literacy } \\
\text { skills, but require effective access } \\
\text { to the Internet to retrieve e- } \\
\text { resources available in the } \\
\text { institution. }\end{array}$ \\
\hline
\end{tabular}




\section{METHODOLOGY}

This paper is a survey research work. Empirical data were collected and analyzed using a questionnaire from three major higher institution in Akwa Ibom State; Akwa Ibom State Polytechnic (AKSP), Akwa Ibom State University (AKSU) and University of Uyo (UNIUYO). A total of 500 questionnaires were administered, out of which, 450 (90.0\%) were returned and 384 (76.8\%) were usable while 66 (13.2\%) were either improperly filled or misused and as such discarded. Table 2 shows the distribution of the questionnaire. The ex-post facto design method was adopted to answer the research questions and test the hypotheses based on the dependents and independent variables of the study. The questionnaire was structure in two sections; A and B. Section A solicited for the respondents' demographic information: gender, age, educational qualifications and institution name. Section $B$ on the other hand, comprises of 20 questions on students information literacy skills on the use of elibrary resources and the performance of students, with 5 (five) point Likert scale, anchored with notations: $1=$ Strongly Disagree, $2=$ Disagree, $3=$ Undecided, $4=$ Agree and $5=$ Strongly Agree.

They were greater responses from the students of AKSU 138 (35.42\%), followed by UNIUYO 128 (33.33\% and AKSP 120 (31.25\%) making a total of 384 respondents. The gender distribution of the respondents in the three institutions under study was 170 (44.27\%) for males and 214 (55.73\%) respondents for females. The study was analyzed using Pearson Product Moment Correlation and Multiple Regression Analysis to determine the composite (joint) and relative effects of the independent variables on the dependent variables in the study. The social demographic information was analyzed using Descriptive Statistics such as frequency count and percentage. Statistical Package for Social Sciences (SPSS) was used for analyses. To ensure the content validity and reliability of the instrument, a draft of questionnaires were administered to faculty members who are experienced in questionnaire design and development. Also a pre-test was carried out outside the sample size and responses from both avenues were used to validate the instrument. This was done to ensure that the content corresponds with the subject matter under consideration.

\section{RESULT AND DISCUSSION}

\subsection{Analysis of Research Questions}

Research Question 1 (RQ1): Is information literacy skill necessary for students in tertiary institutions for improving their academic performance? The data in Table 3 revealed majority of the respondents do not use the university e-libraries resources.

Table 2: Distribution of Questionnaire and Demographic Data of the Respondents

\begin{tabular}{|c|c|c|c|c|c|c|c|c|c|}
\hline \multirow[t]{2}{*}{ Institution } & \multirow{2}{*}{$\begin{array}{l}\text { No. } \\
\text { Distributed }\end{array}$} & \multirow{2}{*}{$\begin{array}{l}\text { No. } \\
\text { Returned }\end{array}$} & \multirow{2}{*}{$\begin{array}{l}\text { Total No. } \\
\text { Usable }\end{array}$} & \multirow{2}{*}{$\begin{array}{l}\text { \% No. } \\
\text { Usable }\end{array}$} & \multicolumn{4}{|c|}{ Sex } & \multirow{2}{*}{$\begin{array}{c}\text { No. } \\
\text { Discarded }\end{array}$} \\
\hline & & & & & $\begin{array}{c}\text { Total Male } \\
\text { usable }\end{array}$ & $\begin{array}{l}\% \text { male } \\
\text { usable }\end{array}$ & $\begin{array}{l}\text { Total } \\
\text { female } \\
\text { usable }\end{array}$ & $\begin{array}{c}\% \text { female } \\
\text { usable }\end{array}$ & \\
\hline AKSP & 140 & 140 & 120 & 31.25 & 56.00 & 46.70 & 64.00 & 53.30 & 20.0 \\
\hline AKSU & 180 & 139 & 136 & 35.42 & 57.00 & 42.00 & 79.00 & 58.00 & 3.00 \\
\hline UNIUYO & 180 & 171 & 128 & 33.33 & 57.00 & 44.50 & 71.00 & 55.50 & 43.00 \\
\hline
\end{tabular}

Table 3: Students'Utilization of the Library Resources

\begin{tabular}{|c|c|c|c|c|c|c|c|c|c|c|c|c|}
\hline \multirow{2}{*}{ Item } & \multirow{2}{*}{$\begin{array}{l}\text { In my institution I } \\
\text { use the library; }\end{array}$} & \multicolumn{2}{|c|}{ Never (1) } & \multicolumn{2}{|c|}{ Seldom (2) } & \multicolumn{2}{|c|}{ Undecided (3) } & \multicolumn{2}{|c|}{ Often (4) } & \multicolumn{2}{|c|}{ Most Often (5) } & \multirow{2}{*}{ Mean (X) } \\
\hline & & No. & $\%$ & No. & $\%$ & No. & $\%$ & No. & $\%$ & No. & $\%$ & \\
\hline 1. & Q1 & 70 & 18.20 & 60 & 16.60 & 50 & 13.00 & 98 & 25.50 & 104 & 27.10 & 3.26 \\
\hline 2. & Q2 & 108 & 28.10 & 94 & 24.50 & 54 & 13.10 & 63 & 16.40 & 65 & 16.90 & 3.26 \\
\hline 3. & Q3 & 106 & 27.60 & 96 & 25.00 & 52 & 13.50 & 68 & 17.70 & 62 & 16.10 & 3.30 \\
\hline 4. & Q4 & 110 & 28.60 & 94 & 24.50 & 53 & 13.80 & 70 & 18.20 & 57 & 14.80 & 3.33 \\
\hline 5. & Q5 & 51 & 13.30 & 73 & 19.00 & 35 & 9.10 & 105 & 27.30 & 120 & 31.30 & 3.44 \\
\hline 6. & Q6 & 83 & 21.60 & 60 & 15.70 & 49 & 12.70 & 77 & 20.00 & 115 & 30.00 & 3.16 \\
\hline & ighted Mean & & & & & & & & & & & 3.29 \\
\hline
\end{tabular}

KEY: Q1. To read personal lecture notes and do my course assignments. Q2. For reading e-mails and e-newspapers, Q3. Computers to search databases such as EBSCO. Q4. Computers and its technologies for e-books, e-journals search, Q5. To consult etheses or past projects and dissertations; Q6. To browse the Internet 
Research Question 2 (RQ2):Is the Possession of Computer Literacy Skill a Prerequisite for Effective use of EResources in the Institution Libraries?

Table 4: Computer Literacy Skills of the students

\begin{tabular}{|c|c|c|c|c|c|c|c|c|c|c|c|c|}
\hline \multirow{2}{*}{ Item } & \multirow{2}{*}{$\begin{array}{c}\text { Computer } \\
\text { Literacy Skills }\end{array}$} & \multicolumn{2}{|c|}{ Very Little(1) } & \multicolumn{2}{|c|}{ Little (2) } & \multicolumn{2}{|c|}{ Average (3) } & \multicolumn{2}{|c|}{ Much (4) } & \multicolumn{2}{|c|}{ Very Much (5) } & \multirow{2}{*}{ Mean $(X)$} \\
\hline & & No. & $\%$ & No. & $\%$ & No. & $\%$ & No. & $\%$ & No. & $\%$ & \\
\hline 7. & Q7 & 97 & 25.30 & 101 & 26.30 & 47 & 12.20 & 63 & 16.40 & 76 & 19.80 & 2.79 \\
\hline 8. & Q8 & 123 & 32.00 & 111 & 28.90 & 40 & 10.40 & 51 & 13.30 & 59 & 15.40 & 2.22 \\
\hline 9. & Q9 & 91 & 23.70 & 87 & 22.70 & 56 & 14.60 & 78 & 20.30 & 72 & 18.80 & 2.89 \\
\hline 10. & Q10 & 78 & 20.30 & 96 & 25.00 & 70 & 18.20 & 73 & 19.00 & 67 & 17.40 & 2.88 \\
\hline 11. & Q11 & 81 & 21.10 & 70 & 18.20 & 90 & 23.40 & 73 & 19.00 & 67 & 17.40 & 2.91 \\
\hline 12. & Q12 & 70 & 18.20 & 72 & 18.80 & 80 & 20.80 & 75 & 19.50 & 87 & 22.70 & 3.09 \\
\hline 13. & Q13 & 62 & 16.10 & 70 & 18.20 & 75 & 19.50 & 80 & 20.80 & 97 & 25.30 & 3.20 \\
\hline 14. & Q14 & 65 & 16.90 & 67 & 1.70 & 74 & 1.90 & 83 & 21.60 & 95 & 24.70 & 3.19 \\
\hline 15 & Q15 & 75 & 19.50 & 82 & 21.40 & 40 & 10.40 & 80 & 20.80 & 107 & 27.90 & 2.95 \\
\hline \multicolumn{2}{|c|}{ Weighted Mean } & & & & & & & & & & & 2.90 \\
\hline
\end{tabular}

KEY: Q7. As a student, I am skilled in using computers Q8. I use computer every day at school; Q9. I use the computer only at the library and am connected to the Internet. Q10. I know how to surf the web to get information I need. Q11. I know how to share resources with other colleagues online. Q12. I work easily with the computer without supervision. Q13. I use computers and IT to solve problems and make decisions. Q14. Lack of literacy skills on use of computers scares me from using computers. Q15. Many of my colleagues have enough literacy skills to use an e-library.

Research Question 3 (RQ3): Is there a remarkable difference between the level of information literacy skills of the students' use of e-resources in Libraries and their academic performance?

Table 5: Effect of Information Literacy Skill and Use of E-Resources on Students'Academic Performance

\begin{tabular}{|c|c|c|c|c|c|c|c|c|c|c|c|c|}
\hline \multirow{2}{*}{ Item } & \multirow{2}{*}{$\begin{array}{c}\text { Academic } \\
\text { Performance } \\
\text { on use of e- } \\
\text { library and } \\
\text { resources. }\end{array}$} & \multicolumn{2}{|c|}{$\begin{array}{l}\text { Strongly Disagree } \\
\text { (1) }\end{array}$} & \multicolumn{2}{|c|}{ Disagree (2) } & \multicolumn{2}{|c|}{ Undecided (3) } & \multicolumn{2}{|c|}{ Agree (4) } & \multicolumn{2}{|c|}{$\begin{array}{l}\text { Strongly Agree } \\
\text { (5) }\end{array}$} & \multirow{2}{*}{ Mean $(X)$} \\
\hline & & No. & $\%$ & No. & $\%$ & No. & $\%$ & No. & $\%$ & No. & $\%$ & \\
\hline 16. & Q16 & 70 & 18.20 & 60 & 15.60 & 50 & 13.00 & 98 & 25.50 & 104 & 27.10 & 3.26 \\
\hline 17. & Q17 & 65 & 16.90 & 63 & 16.40 & 54 & 13.10 & 94 & 24.50 & 108 & 28.10 & 3.26 \\
\hline 18. & Q18 & 62 & 16.10 & 68 & 17.70 & 52 & 13.50 & 96 & 25.00 & 106 & 27.60 & 3.30 \\
\hline 19. & Q19 & 57 & 14.80 & 70 & 18.20 & 53 & 13.80 & 94 & 24.50 & 110 & 28.60 & 3.33 \\
\hline 20. & Q20 & 51 & 13.30 & 73 & 19.00 & 35 & 9.10 & 105 & 27.30 & 120 & 31.30 & 3.44 \\
\hline \multicolumn{4}{|c|}{ Weighted Mean } & & & & & & & & & 3.32 \\
\hline
\end{tabular}

KEY: Q16. I made better grades after relying on e-library resources for my course assignments. Q17. I like using the e-library resources when doing my research Q18. Using computers enable me to acquire more information in my course of study Q19. I find computers and its technologies useful in my research. Q20. I have gained more experience through using e-library resources regularly.

\subsection{Hypothesis Testing}

Three hypotheses were tested at 0.05 significance level. The results of the test are as follows:

\section{Hypotheses one:}

$\mathrm{H}_{0}$ : there is no significant relationship between the use of e-library and students' academic performance.

$\mathrm{H}_{1}$ : There is significant relationship between the use of e-library and students' academic performances.
Table 6: Relationship between use of e-library resources and students' academic performance Correlations

\begin{tabular}{llll}
\hline & & $\mathrm{Y}$ & $\mathrm{X} 1$ \\
\hline & Pearson Correlation & 1 & $.915^{* *}$ \\
Y & Sig. (2-tailed) & & .000 \\
& $\mathrm{~N}$ & 384 & 384 \\
\hline \multirow{3}{*}{ X1 } & Pearson Correlation & $.915^{* *}$ & 1 \\
& Sig. (2-tailed) & .000 & \\
& $\mathrm{~N}$ & 384 & 384 \\
\hline **. Correlation is significant at the 0.05 and 0.01 levels \\
(2tailed).
\end{tabular}


From Table 6, there is a significant strong positive correlation between the students' academic performance and use of e-resources. This shows that the more students make use of e-library resources, the better performance they will achieve.

\section{Hypothesis Two:}

$\mathrm{H}_{0}$ 2: $\quad$ There is no effect of literacy skills on the use of computer and Information Technologies

$\mathrm{H}_{1}$ 2: $\quad$ There is effect of literacy skills on the use of computer and Information technologies

In Table 7, the effect of literacy skills on the use of computer and information technologies are evident in the students' academic performance. Therefore, the adjusted $\mathrm{R}$ square is 0.823 that is $82.3 \%$. This means that literacy skills contribute about $82 \%$ to the effect of the use of computer information technologies.

Table 8 shows that the $\mathrm{R}^{2}$ value of .0824 is not due to chance as it is significant $(\mathrm{F}=1783.907$; $\mathrm{P}<0.05)$. Base on this, the null hypothesis is rejected. Hence, there is significant relationship between the effect of literacy skills and the use of computer information technologies.

Table 9 depicts the effect of literacy skills on the use of computer and information technologies. Since the Pvalue 0.00 is less than the alpha $(\alpha)$ level of 0.05 , it therefore means that there is a significant effect of information literacy skills on the use of computer technologies. Therefore, the null hypothesis of no effect of literacy skills on the use of computer and information technologies is rejected.

\section{Hypothesis Three:}

$\mathrm{H}_{\mathrm{o}} 3$ : student knowledge on the use of e-library resources does not affect their academic performance.

$\mathrm{H}_{1} 3$ : student knowledge of use of e-library resources affects their academic performance

In Table 10, the student knowledge on the use of elibrary resources are evidence in the students' academic performance. Therefore the adjusted $\mathrm{R}$ Square is 0.838 that is $83.8 \%$. This means that the use of e-library resources contribute about $84 \%$ to student academic performances.

Table 11 shows that the $\mathrm{R}^{2}$ value of .0838 is not due to chance as it is significant ( $F=1977.318$; $p<0.05)$. On this basis, the null hypothesis is rejected. Hence, there is effect of student knowledge on the use of e-library resources on students' academic performance.
Table 7: This effect of literacy skills on the use of computer and information technologies. Model Summary

\begin{tabular}{llllll}
\hline Model & $\mathrm{R}$ & $\begin{array}{l}\mathrm{R} \\
\text { Square }\end{array}$ & $\begin{array}{l}\text { Adjusted } \\
\text { Square }\end{array}$ & $\begin{array}{l}\mathrm{R} \\
\text { Std. Error of the } \\
\text { Estimate }\end{array}$ & \\
\hline 1 & $.908^{\mathrm{a}}$ & .824 & .823 & .53623 & \\
\hline
\end{tabular}

a. Predictors: (Constant), X2

Table 8: ANOVA of Regression on the Effect of Literacy Skills on the use of Computer and Information Technologies.

\begin{tabular}{llllll}
\hline Model & Sum of & Df & $\begin{array}{l}\text { Mean } \\
\text { Square }\end{array}$ & F & Sig. \\
& Squares & & Squar & \\
\hline Regression & 512.948 & 1 & 512.948 & 1783.907 & $.000^{\mathrm{b}}$ \\
1Residual & 109.841 & 382 & .288 & & \\
Total & 622.789 & 383 & & & \\
\hline
\end{tabular}

a. Dependent Variable:Y1 b. Predictors: (Constant), X2

Table 9: Test for the effect of Literacy Skills on the use of Computer and Information Technologies

\begin{tabular}{ccccccc}
\hline \multirow{2}{*}{ Model } & \multicolumn{2}{c}{$\begin{array}{c}\text { Unstandardized } \\
\text { coefficient }\end{array}$} & $\begin{array}{c}\text { Standardized } \\
\text { Coefficients }\end{array}$ & & \\
\cline { 2 - 4 } & $\mathrm{B}$ & $\begin{array}{c}\text { Std. } \\
\text { Ttror }\end{array}$ & Beta & & Sig. \\
& & Erron & & \\
\hline $\begin{array}{c}\text { (Constant) } \\
\text { X2 }\end{array}$ & -.356 & .085 & & -4.206 & .000 \\
\hline
\end{tabular}

a. Dependent Variable: $\mathrm{Y} 1$

Table 10: Student knowledge on the use of e-library resources does not affect their academic performance. Model Summary

\begin{tabular}{llllll}
\hline Model & $\mathrm{R}$ & $\mathrm{R}$ & $\begin{array}{l}\text { Adjusted } \\
\text { Square }\end{array}$ & $\mathrm{R}$ & $\begin{array}{l}\text { Std. Error of the } \\
\text { Estimate }\end{array}$ \\
\hline 1 & $.915^{\mathrm{a}}$ & .838 & .838 & .51384
\end{tabular}

a. Predicators: (Constant), X1

Table 11: The ANOVA of the Regression of Student Knowledge on the use of e-library Resources does not affect their Academic Performance ANOVA

\begin{tabular}{|c|c|c|c|c|c|}
\hline Model & $\begin{array}{l}\text { Sum of } \\
\text { Squares }\end{array}$ & Df & $\begin{array}{l}\text { Mean } \\
\text { Square }\end{array}$ & $F$ & Sig. \\
\hline Regression & 522.075 & 1 & 522.948 & 1977.318 & $.000^{\mathrm{b}}$ \\
\hline 1Residual & 100.860 & 382 & .264 & & \\
\hline Total & 622.935 & 383 & & & \\
\hline
\end{tabular}

a. Dependent Variable:Y b. Predictors: (Constant), X1

Table 12: Test for the effect of knowledge on the use of e-library resources on academic performance

\begin{tabular}{llllll}
\hline Model & \multicolumn{2}{l}{$\begin{array}{l}\text { Unstandardized } \\
\text { coefficient }\end{array}$} & $\begin{array}{l}\text { Standardized } \\
\text { Coefficients }\end{array}$ & & S \\
\cline { 2 - 4 } & $\mathrm{B}$ & Std. Error & Beta & & \\
\hline $\begin{array}{l}\text { (Constant) } \\
1\end{array}$ & -.673 & .087 & & -7.745 & .000 \\
X1 & .990 & .022 & .915 & 44.467 & .000 \\
\hline
\end{tabular}

a. Dependent Variable: $\mathrm{Y}$

Since the P-value 0.00 is less than the alpha $(\alpha)$ level of 0.05 , it therefore suffice that there is a significant effect of the use of e-library resources on students' academic 
performance. The null hypothesis of student knowledge on the use of e-library resources does not affect their academic performance is rejected.

RQ1 reveals that out of the twenty (20) items listed only eight (8) items had high use rate while twelve (12) had low rate. Majority of the respondent use the library to read personal lecture notes for class assignments or examination, to borrow books and to read newspapers. Other use of e-library include to read library books, do individual project and finally consult encyclopedia. This reveals a general low level use of the university libraries in Nigeria confirming [23] reports which reveals that library use for all of the academic library experiences was generally low.

RQ2 shows that for the student to effectively use elibrary resources they should possess an appreciable amount of knowledge. In Table 3, the mean of responses from item 7 to item 15 are 2.79, 2.22, 2.89, 2.88, 2.91, 3.09, 3.09, 3.20, 3.19 and 2.95 respectively with weighted mean of 2.90 which is below 3.00 indicating negative responses. The result reveals that most of the respondents lacked the necessary computer literacy skills in using e-library resources and other internet technologies which has affected the use of e-library resources. This supports [24], who argued that library was an important resource for every scholar.

RQ3 reveals a great difference in the academic performance of students in the tertiary institutions who possess adequate literacy skills and as a result they make use of library resources more than those who do not possess the literacy skills. From Table 5, the mean of responses in items 16,17, 18, 19 and 20 are $3.26,3.26,3.30,3.33$ and 3.44 respectively with weighted mean average of 3.32 which is above 3.00 indicating positive responses. This means that students make better grades when they use computers, e-library resources and other IT technologies when doing their assignments and researches thereby improving their academic performance.

In Hypothesis One, the result of the analysis shows that there is a significant strong positive correlation between the students' academic performance and the use of e-library resources. This therefore means that, the more students make use of e-library resources, the better performances they will achieve. E-library resources supports high quality information service network hence, providing access to full range of learning and teaching materials in various formats. This confirms what [24] said, that e-library resources enhance learning and teaching both far and near as the facilities provide both teachers and students with vast quantities of information in an easily accessible and non-sequential format. Also, [13] purported that undergraduate students were successful in locating information needs in the library and this encouraged them to effectively use the library and its resources.

Hypothesis Two reveals literacy skill in computer and information technologies acquired determine the level at which a student is able to search, identify and retrieve information. This is supported by $[21,22,25$, 26], who found out that there was low or no Information and Communication Technology (ICT) skills among respondents at the University of Ilorin and Delta State University, Abraka, Nigeria respectively and as such limited them in the use of e-resources. In order to utilize the growing range of electronic resources, students must acquire and practice the skills necessary to exploit them. Therefore there is a significant effect of literacy skills on the use of computer and information technology. Finally, Hypothesis Three shows that student knowledge on the use of e-library resources affects their academic performances. All independent variables in this study put together have significant relationship to undergraduate's students' use of university libraries e-resources. This supports [1], which argue that library was an important resource for every scholar.

\section{CONCLUSION}

The influence of computer literacy is paramount to the academic performance of the students. The ability to find and retrieve information effectively is a transferable skill useful for future endeavour as well as enabling the positive and successful use of the electronic resources while in the university. The study revealed that undergraduate students do not highly utilize the available electronic resources and the subject background has not influenced the use of electronic resources. This is because they lack awareness of the available electronic resources in the library. While computer literacy greatly influences use of e-resources, subject to background is the reverse, this is because of some inhibiting factors on the use of e-resources which cut across unavailability and inaccessibility of e-resources, lack of awareness and training, lack of requisite computer skills and unstable power supply. Based on these findings of the study, one would conclude that computer literacy skills influenced use of e-resources by undergraduate students in tertiary institutions in Akwalbom State. Whereas eresources were widely available to meet the information needs of the undergraduate students no matter the discipline, many could not substantially 
utilize them because of either low computer literacy skills or ignorance of their availability and relevance.

\section{REFERENCES}

[1] Webber, S. and Johnston, B. "Information literacy in higher education: a review and case study", Studies in higher education, Vol. 28, No. 3, 2003, pp.

335-352.

http://www.ifla.org/IV/ifla69/papers/199e-

Webber.pdf Accessed on October 24, 2016.

[2]. Creswell, J. W., Educational research: Planning, conducting, and evaluating quantitative and qualitative research. Upper Saddle River, New Jersey; Columbus, Ohio: Pearson Education Inc., 2008, pp. $23-40$, http://www.aare.edu.au/08pap/bai08493.pdf, Accessed on October 24, 2016.

[3] Boaduo, N. A. and Babitseng, S. M., "The need for teachers to be researchers", The African Symposium: An Online Journal of African Education Network. Vol. 7, No. 1, pp. 183-191, 2007.

[4] Ani, O. E. and Ahiauzu, B., "Towards effective development of electronic information resources in Nigerian University libraries". Lib. Manage. Vol. 29, No.6, pp. 504-514. 2008.

[5] Ajegbomogun, F. O. and Akintola, B. O., "Gateway Library Journal: A contents analysis", Gateway Library Journal Vol.7 No.1, pp. 87-98, 2004.

[6] American Library Association, Information Literacy: a Position Paper on information Problem Solving, $\quad$ http://www.ala.org/aasl/positions/ ps infolit.html Accessed on July 24, 2015.

[7] Catts, R. and Lau, J., Towards Information Literacy Indicators. Paris: UNESCO, p. 201, 2008.

[8] Parang, E. M., Raine, M. and Stevenson, T., "Redesigning freshman seminary library instruction based on information competencies", Research Strategies, Vol. 17, No. 4, pp. 269-280, 2001.

[9] Bawden, D., Devon, T. K. and Sinclair, I. W., "Desktop information systems and services: A user survey in a pharmaceutical research organization". International Journal of Information Management, Vol. 20, pp. 151-160, 2000.

[10] Lawal, O. O. and Okwueze, E. U., "Library Funding and Journal Collection Development in Nigerian University Libraries", Gateway Library J. Vol.10, No. 1, pp. 1-12, 2007.

[11] Mutshewa, A., "Enhancing Access through Electronic Resources: The University of Botswana
Experience", Lib. High Technol. Vol. 18, No.4, pp. 315-320, 2000.

[12] Tenopir, C., "Use and users of electronic library resources: An overview and analysis of recent research studies", Council on Library and Information Resources, 2003, p. 1-12, http://www.clir.org/pubs/ reports/pub120.pdf Accessed on August 10, 2016.

[13] Waldman, M., “Freshmen's Use of Library electronic resources and self-efficacy", 2003. http://information.net/ir/8 21paper150, Accessed on November 10, 2016.

[14] Korobili, S., Irene, T. and Antonia, D., "Factors that influence the use of library resources by faculty members", Library Review, Vol. 55, No. 2, pp. 91105, DOI 10.1108/0024253061064959, 2006.

[15] Ugah, D., "Availability and Accessibility of Information Sources and the Use of Library Services at Michael Okpara University of Agriculture", Library Philosophy and Practice, pp. 92-98, 2008.

[16] Edem, N. and Egbe, N., "Availability and Utilization of Electronic Resources by Postgraduate Students in a Nigerian University Library: A Case Study of University of Calabar, Nigeria", Information and Knowledge Management, Vol. 6, No. 2, p.1, 2016.

[17] Oyewusi, F. O. and Oyeboade, S. A., "An Empirical Study of Accessibility and Use of Library Resources by Undergraduates in a Nigerian State University of Technology", Library Philosophy and Practice. 2009, http://www.webpages.uidaho. edu/ mbolin/oyewusioyeboade, Accessed on October 24, 2015.

[18] Ndem, N., Ani, O. and Ocheibi, J., "Student perceived effectiveness in the use of library resources in Nigerian universities", Journal of Educational research and review, Vol. 4, No., 6, pp. 332-326. 2009.

[19] Agaba, D. M., Assessment of the Utilization of Makerere University Electronic Information Resources by Academic Staff: Challenges and Prospects, 2010, https://research.libraries.wsu.edu/xmlui/bitstrea $\mathrm{m} /$ handle/2376/1447/Agaba $\% 20$ Assessment $\% 2$ 0of\%20the $\% 20$ utilization.pdf?sequence $=1 \&$ isAll owed =y Accessed on April 12, 2017.

[20] Okon, M. E. Etuk, E. P. and Akpan, U. J., "Information Literacy Skills and Information use by Students in two South University Libraries in Nigeria", International Journal of Economics, Commerce, and Management, Vol. 2, Issue 1, pp. 116, 2014.

[21] Issa, A. O., Blessing, A. and Daura, U. D., "Effects of Information Literacy Skills on the Use of E-Library Resources among Students of the University of 
Ilorin, Kwara State, Nigeria", Library Philosophy and Practice (e-journal). 2009, pp.111, http://digitalcommons.unl.edu/libphilprac/2 45.Accessed on October 6, 2017.

[22] Toyo, O. D., Undergraduates' Information Literacy Skills and the Use of Electronic Resources in Delta State University, Abraka, Nigeria, International Journal of Education and Evaluation, Vol. 3, No. 1., pp.28-35, 2017.

https://www.iiardpub.org/get/IJEE/VOL.\%203\%20NO $\% 201 \% 202017 /$ UNDERGRADUATES $\%$ E2\%80\% 99\%20INFORMATION.pdf. Accessed on October 6, 2017.

[23] Walton, T., Objectives and library publications, 2010, http://www.iboro.ac.uk/library/about Lobjectives.htm, Accessed on December 23, 2016.
[24] Mcharazo, M., "Synergising Technology with cognition and Pedagogy: A framework for designing e-learning programs", Paper presented in the National conference of the Philippine elearning Society. 1-2 August, 2006.

[25] Bashorun, M. T., Isah, A. and Adisa, M. Y., "User Perception of Electronic Resources in the University of Ilorin, Nigeria", Journal of Emerging Trends in Computing Inform. Sci., Vol. 2, No. 11, pp. 557-562, 2011.

[26] Ozoemelem, O. A., "Use of Electronic Resources by Postgraduate Students of the Department of Library and Information Science of Delta State University, Abraka, Nigeria", Library Philosophy and Practice, 2009, http://digitalcommons. unl.edu/cgi/viewcontent.cgi?article $=1306 \&$ conte xt=libphilprac, Accessed on December 23, 2016. 